Asian Pacific Journal of Reproduction

Journal homepage: www.apjr.net

\title{
Preservability of bull spermatozoa in Tris-egg yolk extender enriched with different concentrations of butylated hydroxytoluene
}

El-Sheshtawy RI ${ }^{\bowtie}$, El-Nattat WS, El-Sisy GA

Animal Reproduction and AI Dept., Veterinary Research Division, National Research Centre, Dokki, Egypt

\section{ARTICLE INFO}

Article history:

Received 20 December 2016

Revision 2 February 2017

Accepted 12 February 2017

Available online 1 March 2017

\section{Keywords:}

Cattle

Semen

Preservation

BHT

\section{Introduction}

There are many advantages upon application of a breeding program using cryopreserved semen. The most important benefit is the long-term storage of genetic material. There are many factors affecting survival of cryopreserved spermatozoa[1]. Sperm freezing protocols differ from species to another. This species difference is related to variations in seminal plasma and membrane compositions

\footnotetext{
Corresponding author: Reda, I., El sheshtawy, Animal Reproduction and Artificia Insemination Department, National Research Centre, Dokki, Giza, Egypt.

Tel: 20233371635

Fax: 202-37601877

E-mail: rielsheshtawy@gmail.com
}

\begin{abstract}
Objective: To explore the effect of BHT on cattle spermatozoa during cooling and cryopreservation. Methods: Pooled bull semen were diluted by Tris-Citrate-Fructose egg yolk (TCFY) diluent considered as control (0 BHT) and different concentrations of BHT (1.0, 2.0, 3.0, 4.0, 5.0 and $6.0 \mathrm{mM}$ were prepared in ethanol in prewarmed $\left(37^{\circ} \mathrm{C}\right)$ test tubes. The ethanol was allowed to evaporate so that, a thin crystallized layer of BHT was deposited on the inner surface of the tubes. Then extended semen was added into the tubes and incubated at $37{ }^{\circ} \mathrm{C}$ for 5 min to allow uptake of BHT by spermatozoa. The tubes were cooled slowly (approximately for $2 \mathrm{~h}$ ) up to $5{ }^{\circ} \mathrm{C}$ and equilibrated for $4 \mathrm{~h}$. After equilibration, semen freezing process was carried out. Extended semen was subjected to evaluation (motility, alive sperm, intact sperm membrane (HOST) \% and acrosome integrity) in both cooled and cryopreserved semen. Results: The result revealed that sperm motility of post-cooled spermatozoa improved $(P<0.05)$ by the use of BHT concentrations $(1,2$ and $3 \mathrm{mM})$ in Tris semen extender if compared to the control $(85.00 \pm 1.09),(83.33 \pm 0.63),(81.67 \pm 0.63)$ and $(78.33 \pm 0.63)$, respectively. Alive sperm percent was significantly higher in all concentrations of BHT. Sperm abnormalities percent were significantly lower in concentrations of BHT 1 and $2(11.2 \pm 0.2),(11.8 \pm 0.2)$ and $(13.4 \pm 0.4)$, respectively. Sperm membrane integrity were significantly higher in BHT concentrations (1, 2, 3, 4 and $5 \mathrm{mM}$ ). It is exhibited that improved sperm motility in post-thawed frozen semen in the concentrations of $\mathrm{BHT}(1,2,3$ and $4 \mathrm{mM})$ if compared to the control. The sperm membrane integrity were significantly improved at all concentrations of BHT. Acrosome

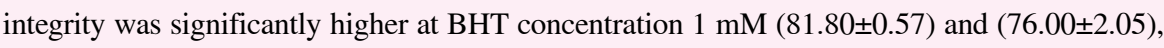
respectively. Conclusions: It could be concluded that some concentrations of BHT improved bull semen quality post-cooling and post-freezing.
\end{abstract}

between species[2]. Freeze thaw process has detrimental effects on spermatozoa as it induces lipid peroxidation[3] exerted by over accumulation of reactive oxygen species (ROS) causing oxidative damage to sperm membrane, acrosome and DNA, then finally loss of sperm viability[4-6]. Susceptibility to lipid peroxidation differs among species and also due to changes in cryopreservation protocol,

\footnotetext{
This is an open access article distributed under the terms of the Creative Common Attribution-Non Commercial-Share Alike 3.0 License, which allows others to remix, tweak and buid upon the work non-commercially, as long as the author is credited and the new creations are licensed under the identical terms.

For reprints contact: reprints@medknow.com

C2017 Asian Pacific Journal of Reproduction Produced by Wolters Kluwer- Medknow

How to cite this article: El-Sheshtawy RI, El-Nattat WS, El-Sisy GA. Preservability of bull spermatozoa in Tris-egg yolk extender enriched with different concentrations of butylated hydroxytoluene. Asian Pac J Reprod 2017; 6(2): 77-80.
} 
extender formula and antioxidant concentration[7]. The spermatozoa membrane is the most susceptible part to the oxidative damage due to its high contents of polyunsaturated fatty acids and its deficiency of protecting enzymes[1,8-12], as GSH, CAT and SOD and metal chelators as transferring, lactoferrin and cerruloplasmin. Therefore, addition of antioxidants to the extender induce beneficial effects on spermatozoa via reducing the cryoinjury induced by ROS[13-20]. BHT is a synthetic analogue of vitamin E that has positive effects on semen quality of frozen bull semen[21], ram[22], boar[23], goat[24] and turkey[25].

BHT is one of the most important antioxidants that could be used in semen extenders as a cryoprotectant[1]. There is little literature with respect to its use in cattle bulls. So, the aim of the present study was to explore the effect of BHT on cattle spermatozoa during cooling and cryopreservation.

\section{Material and methods}

\subsection{Semen collection and initial evaluation}

Five mature genetically improved cattle-bulls with superior quality semen characteristics maintained at The Semen Freezing Center, General Organization for Vet. Services, Ministry of Agriculture, Abbasia, Egypt, were used for this study as semen source. Semen ejaculates were collected from bulls using an artificial vagina at weekly intervals for $5 \mathrm{wk}$. The semen samples were initially evaluated for volume (in graduated tube), concentration using Thoma rulling of the Neubaur haemocytometer and sperm motility. The neat semen samples with more than $70 \%$ motility and $80 \%$ morphologically normal spermatozoa were admitted to freezing procedure. The ejaculates were pooled in order to have sufficient semen for a replicate and to eliminate the bull effect. The semen was given a holding time for $10 \mathrm{~min}$ at $37{ }^{\circ} \mathrm{C}$ in a water bath before dilution to be evaluated for sperm motility, viability, total abnormalities, and acrosome and membrane integrities before processing.

\subsection{Semen processing}

Semen samples were extended (1:7 dilution rate) in a Tris-citrate egg yolk extender with $20 \%$ (v/v) egg yolk and $7 \%$ (v/v) glycerol at $37^{\circ} \mathrm{C}[26,27]$ to ensure 60 million motile spermatozoa mL-1.

Different concentrations of BHT (1.0, 2.0, 3.0, 4.0, 5.0 and 6.0 $\mathrm{mM}$ were prepared in ethanol in prewarmed $\left(37^{\circ} \mathrm{C}\right)$ test tubes. The ethanol was allowed to evaporate so that a thin crystallized layer of BHT was deposited on the inner surface of the tubes. Then extended semen was added into the tubes and incubated at $37^{\circ} \mathrm{C}$ for 5 min to allow uptake of BHT by spermatozoa[28]. The control tubes were Tris containing (0 BHT). The tubes were cooled slowly (approximately for $2 \mathrm{~h}$ ) up to $5{ }^{\circ} \mathrm{C}$ and equilibrated for $4 \mathrm{~h}$. Semen was packed into $0.25 \mathrm{~mL}$ polyvinyl French straws (IMV, France). After equilibration periods, the straws were placed horizontally on a rack and frozen in a vapor $4 \mathrm{~cm}$ above liquid nitrogen (LN2) for $10 \mathrm{~min}$ and were then dipped stored in liquid nitrogen at $-196^{\circ} \mathrm{C}$.

\subsection{Assessment of semen quality parameters}

Frozen straws were thawed individually at $37^{\circ} \mathrm{C}$ for $30 \mathrm{~s}$ in a water bath for microscopic evaluation[29]. The parameters studied were sperm motility, sperm viability, sperm abnormality, sperm membrane integrity (HOST), percent of normal intact acrosome in cooled and frozen-thawed semen.

\subsubsection{Sperm motility}

Subjective motility was observed using phase contrast microscope (Olympus Optical Co. Ltd., Japan). Visual motility was assessed microscopically with closed circuit television[30].

\subsubsection{Live and abnormal spermatozoa (\%)}

The viability and abnormalities\% of sperm were evaluated using eosin-Nigrosin stained smear as described by Sidhu and Guraya[31].

\subsubsection{Sperm membrane integrity}

Sperm membrane integrity was assessed using the hypoosmotic swelling test[32]. Two hundred spermatozoa were assessed and the percentage of spermatozoa with curled tails (swollen/intact plasma membrane) was calculated.

\subsubsection{Intact normal acrosome percent}

Acrosome integrity was evaluated using giemsa stain as described by Watson[33]. The \% intact acrosome was recorded for 200 spermatozoa that were randomly examined under an immersion objective ( $\times 1000$ magnification) using phase contract microscope.

\subsubsection{Statistical analysis}

Output data were analyzed by one-way analysis of variance (ANOVA), followed by Duncan test to determine significant differences in all the parameters among all groups, with SPSS Version 14.0 for Windows[34]. Differences with values of $P<0.05$ were considered to be statistically significant.

\section{Results}

Table 1 revealed that sperm motility of post-cooled spermatozoa improved $(P<0.05)$ by the use of BHT concentrations $(1,2$ and $3 \mathrm{mM}$ ) in Tris semen extender if compared to the control $(85.00 \pm 1.09),(83.33 \pm 0.63),(81.67 \pm 0.63)$ and $(78.33 \pm 0.63)$, respectively. Alive sperm percent was significantly higher $(P<0.05)$ in all concentrations of BHT if compared to the control. Sperm abnormalities percent were significantly lower in concentrations of BHT 1 and 2 with respect to the control $(11.2 \pm 0.2),(11.8 \pm 0.2)$ and (13.4 \pm 0.4$)$, respectively. Sperm membrane integrity (HOST \%) were 
significant $(P<0.05)$ higher in BHT concentrations $(1,2,3,4$ and 5 $\mathrm{mM})$ as compared to the control.

Table 1

Effect of Tris extender enriched with BHT on the cooled extended bull semen.

\begin{tabular}{ccccc}
\hline Parameter(\%) & Motility & Alive & Abnormality & HOST \\
\hline Control & $78.33 \pm 0.63^{\mathrm{c}}$ & $79.67 \pm 1.24^{\mathrm{c}}$ & $13.40 \pm 0.40^{\mathrm{c}}$ & $71.42 \pm 0.10^{\mathrm{d}}$ \\
BHT 1 & $85.00 \pm 1.09^{\mathrm{a}}$ & $91.20 \pm 0.39^{\mathrm{ab}}$ & $11.20 \pm 0.20^{\mathrm{d}}$ & $79.67 \pm 0.33^{\mathrm{a}}$ \\
2 & $83.33 \pm 0.63^{\mathrm{ab}}$ & $91.00 \pm 0.24^{\mathrm{ab}}$ & $11.80 \pm 0.20^{\mathrm{d}}$ & $77.67 \pm 0.55^{\mathrm{b}}$ \\
3 & $81.67 \pm 0.63^{\mathrm{b}}$ & $92.00 \pm 0.38^{\mathrm{a}}$ & $15.80 \pm 0.52^{\mathrm{b}}$ & $75.33 \pm 0.67^{\mathrm{c}}$ \\
4 & $78.33 \pm 0.63^{\mathrm{c}}$ & $91.60 \pm 0.58^{\mathrm{ab}}$ & $16.40 \pm 0.36^{\mathrm{b}}$ & $75.33 \pm 0.55^{\mathrm{c}}$ \\
5 & $78.33 \pm 0.63^{\mathrm{c}}$ & $91.40 \pm 0.27^{\mathrm{ab}}$ & $16.20 \pm 0.31^{\mathrm{b}}$ & $75.33 \pm 0.77^{\mathrm{c}}$ \\
6 & $73.33 \pm 0.63^{\mathrm{d}}$ & $90.20 \pm 0.26^{\mathrm{b}}$ & $19.40 \pm 0.40^{\mathrm{a}}$ & $70.00 \pm 0.44^{\mathrm{e}}$ \\
F-cal & 29.81 & 57.42 & 65.73 & 40.15 \\
$P<$ & 0.0001 & 0.0001 & 0.0001 & 0.0001 \\
\hline
\end{tabular}

The different superscripts within rows indicate significant differences between means compared with the Duncan's multiple range test $(P<0.05)$.

Table 2 exhibited improved sperm motility in post-thawed frozen semen in the concentrations of BHT $(1,2,3$ and $4 \mathrm{mM})$ if compared to the control. The sperm membrane integrity (HOST\%) were significantly $(P<0.05)$ improved at all concentrations of BHT if compared to the control.

Acrosome integrity was significantly $(P<0.05)$ higher at BHT concentration $1 \mathrm{mM}$ as compared to the control $(81.80 \pm 0.57)$ and (76.00 \pm 2.05$)$, respectively.

Table 2

Effect of Tris extender enriched with BHT on the freezed thawed extended bull semen.

\begin{tabular}{|c|c|c|c|c|c|c|}
\hline \multicolumn{2}{|c|}{$\begin{array}{l}\text { Parameter } \\
(\%) \\
\end{array}$} & Motility & Alive & $\mathrm{Ab}$ & HOST & $\begin{array}{l}\text { Acrosome } \\
\text { integrity }\end{array}$ \\
\hline \multicolumn{2}{|c|}{ Control } & $41.00 \pm 1.00^{\mathrm{d}}$ & $80.60 \pm 0.95^{\mathrm{a}}$ & $18.50 \pm 1.09^{\mathrm{a}}$ & $71.20 \pm 0.62^{\mathrm{e}}$ & $76.00 \pm 2.05^{\mathrm{ab}}$ \\
\hline \multirow[t]{6}{*}{ BHT } & 1 & $54.00 \pm 1.31^{\mathrm{b}}$ & $73.00 \pm 2.20^{\mathrm{b}}$ & $17.50 \pm 1.53^{\mathrm{a}}$ & $84.00 \pm 0.79^{a}$ & $81.80 \pm 0.57^{\mathrm{a}}$ \\
\hline & 2 & $58.00 \pm 1.07^{\mathrm{a}}$ & $71.80 \pm 0.80^{\mathrm{b}}$ & $18.67 \pm 0.65^{\mathrm{a}}$ & $83.33 \pm 0.77^{\mathrm{a}}$ & $74.60 \pm 3.41^{\mathrm{b}}$ \\
\hline & 3 & $45.00 \pm 1.46^{\mathrm{c}}$ & $60.80 \pm 2.26^{\mathrm{cd}}$ & $19.67 \pm 1.05^{\mathrm{a}}$ & $84.67 \pm 0.77^{\mathrm{a}}$ & $75.20 \pm 2.67^{b}$ \\
\hline & 4 & $44.00 \pm 1.31^{\mathrm{c}}$ & $64.00 \pm 2.12^{c}$ & $18.33 \pm 1.64^{\mathrm{a}}$ & $80.67 \pm$ & $60.80 \pm 2.40^{c}$ \\
\hline & 5 & $37.00 \pm 1.07^{\mathrm{e}}$ & $58.80 \pm 2.30^{\mathrm{d}}$ & $17.78 \pm 0.40^{\mathrm{a}}$ & $78.67 \pm 0.77^{\mathrm{c}}$ & $59.00 \pm 1.66^{\mathrm{c}}$ \\
\hline & 6 & $25.00 \pm 0.85^{\mathrm{f}}$ & $45.67 \pm 0.96^{\mathrm{e}}$ & $17.82 \pm 0.35^{\mathrm{a}}$ & $74.33 \pm 0.98^{\mathrm{d}}$ & $59.40 \pm 2.23^{\mathrm{c}}$ \\
\hline \multicolumn{2}{|l|}{ F-cal } & 87.00 & & & 47. & 17.15 \\
\hline \multicolumn{2}{|l|}{$P<$} & 0.0001 & 0.8317 & 0.0001 & 0.0001 & 0.0001 \\
\hline
\end{tabular}

The different superscripts within rows indicate significant differences between means compared with the Duncan's multiple range test $(P<0.05)$.

\section{Discussion}

The generation of ROS resulting from cryopreservation[14] and the reduced activity of the antioxidant enzymes in semen postfreezing $[11,35,36]$ bay be the causative factor of sperm cryoinjury, therefore, the addition of BHT as an antioxidant in buffalo semen extenders[28] in ram[37], in goat[7] and in canine[1] can improve postthawed semen quality.

The results of the present study showed improved post-cooling and post-thawing semen quality in terms of motility, viability, acrosomal and sperm membrane integrities in Tris extender enriched with BHT. Our results are in agreement with those obtained in buffalo bulls[28], in bulls[5,21,38], ram[22], goat[24,39] and boar[23,40]. Also, our results are in accordance with Shoae and Zamir[21] who stated improved post-freezing semen quality with concentrations $0.5-1.0 \mathrm{mM}$ BHT in bulls. However, they concluded that higher concentrations of BHT have detrimental effects. The improved post-thawed sperm motility in this study may be attributed to the protective antioxidant effect of BHT on morphological sperm integrity especially the integrity of the axosoma and mitochondria of the middle piece[7]. The improvement in post-cooling and post-freezing semen quality in our study may be due to the incorporation of BHT into the cell membrane increasing its integrity and fluidity[21]. This effect could be conducted by the antilipid peroxidation action of BHT[41-44]. In contrast to this, Ball et al.[45] observed detrimental effects of BHT supplement on stallion spermatozoa.

These findings could be related to species varieties in susceptibility to oxidative stress[46,47]. It could be concluded that some concentrations of BHT improved bull semen quality post-cooling and post-freezing.

\section{Conflict of interest statement}

The authors declare that they have no conflict of interest.

\section{References}

[1] NeaguVR, GarcíaBM, Sandoval CS, Rodríguez AM, Ferrusola CO, et al. Freezing dog semen in presence of the antioxidant butylated hydroxytoluene improves post thaw sperm membrane integrity. Theriogenology 2010; 73(5): 645-650.

[2] Bencharif D, Amirat L, Anton M, Schmitt E, Desherces S, Delhomme $\mathrm{G}$, et al. The advantages of LDL (low density lipoproteins) in the cryopreservation of canine semen. Theriogenology 2008; 70(9): 14781488.

[3] Brouwers J, Gadella BM. In situ detection and localization of lipid peroxidation in individual bovine sperm cells. Free Radic Biol Med 2003; 35(11): 1382-1391.

[4] Aumuller G, Seitz J. Protein secretion and secretory processes in male accessory sex glands. Int Rev Cytol 1990; 121: 127-231.

[5] Anderson S, Harkness W, Akin Y, Kaproth M, Killian G. Categorical data analysis of the effect on bull fertility of butylated hydroxytoluene addition to semen extenders prior to freezing. J Dairy Sci 1994; 77(8): 2302-2307.

[6] Mammoto A, Masumoto N, Tahara M, Ikebuchi Y, Ohmichi M, Tasaka K. Reactive oxygen species block sperm-egg fusion via oxidation of sperm sulfhydryl proteins in mice. Biol Reprod 1996; 55(5): 1063-1068.

[7] Memon AA, Wahid H, Rosnina Y, Goh YM, Ebrahimi M, Nadia FM. Effect of antioxidants on post thaw microscopic, oxidative stress parameter and fertility of Boer goat spermatozoa in Tris egg yolk glycerol extender. Anim Reprod Sci 2012; 136(1-2): 55-60.

[8] Agarwal A, Saleh RA. Role of oxidants in male infertility: Rationale, significance and treatment. Urol Clin North Am 2002; 29(4): 817-827.

[9] Alvarez JG, Storey BT. Role of glutathione peroxidase in protecting mammalian spermatozoa from loss of motility caused by spontaneous lipid peroxidation. Gamete Res 1989; 23(1): 77-90.

[10]Beconi MT, Affranchino MA, Schang LM, Beorlegui NB. Influence of antioxidants on SOD activity in bovine sperm. Biochem Int 1991; 23(3): 
545-553.

[11]Bilodeau JF, Chatterjee S, Sirard MA, Gagnon C. Levels of antioxidant defenses are decreased in bovine spermatozoa after a cycle of freezing and thawing. Mol Reprod Dev 2000; 55(3): 282-288.

[12]Zini A, Lamirande ED, Gagnon C. Reactive oxygen species in semen of infertile patients: Levels of superoxide dismutase and catalase-like activities in seminal plasma and spermatozoa. Int J Androl 1993; 16(3): 183-188.

[13]Aitken RJ, Harkiss D, Buckingham D. Relationship between ironcatalysed lipid peroxidation potential and human sperm function. $J$ Reprod Fertil 1993; 98(1): 257-265.

[14]Aitken RJ. Free radicals, lipid peroxidation and sperm function. Reprod Fertil Dev 1995; 7(4): 659-668.

[15]Khalifa TAA, El Saidy BE. Pellet-freezing of damascus goat semen in a chemically defined extender. Anim Reprod Sci 2006; 93(3-4): 303-315.

[16]Khan MIR, Ijaz A. Assessing undiluted, diluted and frozen-thawed NiliRavi buffalo bull sperm by using standard semen assays. Ital J Anim Sci 2007; 6(2s): 784-787.

[17]Lewis SE, Sterling ES, Young IS, Thompson W. Comparison of individual antioxidants of sperm and seminal plasma in fertile and infertile men. Fertil Steril 1997; 67(1): 142-147.

[18] Shannon P, Curson B. Kinetics of the aromatic L-amino acid oxidase from dead bovine spermatozoa and the effect of catalase on fertility of diluted bovine semen stored at 5 degrees $\mathrm{C}$ and ambient temperatures. $J$ Reprod Fertil 1982; 64(2): 463-467.

[19]Storey BT. Biochemistry of the induction and prevention of lipoperoxidative damage in human spermatozoa. Mol Hum Reprod 1997; 3(3): 203-213.

[20]Upreti GC, Jensen K, Munday R, Duganzich DM, Vishwanath R, Smith JF. Studies on aromatic amino acid oxidase activity in ram spermatozoa: Role of pyruvate as an antioxidant. Anim Reprod Sci 1998; 51(4): 275287.

[21]Shoae A, Zamiri MJ. Effect of butylated hydroxytoluene on bull spermatozoa frozen in egg yolk-citrate extender. Anim Reprod Sci 2008; 104(2-4): 414-418.

[22]Watson P, Anderson W. Influence of butylated hydroxytoluene (BHT) on the viability of ram spermatozoa undergoing cold shock. J Reprod Fertil 1983; 69(1): 229-235.

[23]Roca J, Gil MA, Hernandez M, Parrilla I, Vazquez JM, Martinez EA. Survival and fertility of boar spermatozoa after freeze-thawing in extender supplemented with butylated hydroxytoluene. J Androl 2004; 25(3): 397-405

[24]Khalifa TAA, Lymberopoulos AG, ElSaidy BE. Testing usability of butylated hydroxytoluene in conservation of goat semen. Reprod Domest Anim 2008; 43(5): 525-530.

[25]Donoghue AN, Donoghue DJ. Effects of water and lipid-soluble antioxidants on turkey sperm viability, membrane integrity, and motility during liquid storage. Poult Sci 1997; 76(10): 1440-1445.

[26]de Paz P, Esteso MC, Alvarez M, Mata M, Chamorro CA, Anel L. Development of extender based on soybean lecithin for its application in liquid ram semen. Theriogenology 2010; 74(4): 663-671.

[27]Roof DJ, Bowley S, Price LL, Matsas DJ. Comparison of two commercial extenders for cryopreservation of goat semen without sperm washing. Theriogenology 2012; 77(2): 412-420.

[28]Ijaz A, Hussain A, Aleem M, Yousaf MS, Rehman H. Butylated hydroxytoluene inclusion in semen extender improves the post thawed semen quality of Nili-Ravi buffalo (Bubalus bubalis). Theriogenology 2009; 71(8): 1326-1329.

[29] Ashrafi I, Kohram H, Naijian H, Bahreini M, Mirzakhani H. Effect of controlled and uncontrolled cooling rate on motility parameters of cryopreserved ram spermatozoa. BMC Res Notes 2011; 4: 547.

[30] Graham EF, Schmehl MKL, Maki-lauria M. Some physical and chemical methods of evaluating semen. In: Proc. 3rd NAAB, Tech Conf Artif Insemin Reprod, editor. Columbia, MO: National Association of Animal Breeders; 1970, p. 24.

[31] Sidhu KS, Guraya SS. Buffalo bull semen morphology, biochemistry, physiology and methodology. Ludhiana: USA Publishers and Distributors; 1985, p. 152-154.

[32]Jeyendran RS, Vander Ven HH, Perez Pelaez M, Crabo BG, Zaneveld LJD. Development of an assay to assess the functional integrity of the human sperm membrane and its relationship to other semen characteristics. J Reprod Fertil 1984; 70(1): 219-228.

[33] Watson PF. Use of giemsa stain to detect changes in the acrosome of frozen ram spermatozoa. Vet Rec 1975; 97(1): 12-15.

[34]SPSS v.14.0 for Windows Evaluation Version Release 2005; 14.0.0.

[35]Bucak MN, Atessahin A, Yüce A. Effect of anti-oxidants and oxidative stress parameters on ram semen after the freeze-thawing process. Small Rumin Res 2008; 75(2-3): 128-134.

[36]Martí E, Marti JI, Muiñno-Blanco T, Cebrián-Pérez JA. Effect of the cryopreservation process on the activity and immunolocalization of antioxidant enzymes in ram spermatozoa. J Androl 2008; 29(4): 459-467.

[37]Maia MDS, Bicudo SD, Sicherle CC, Rodello L, Gallego ICS. Lipid peroxidation and generation of hydrogen peroxide in frozen-thawed ram semen cryopreserved in extenders with antioxidants. Anim Reprod Sci 2010; 122(1-2): 118-123.

[38]Chatterjee S, Gagnon C. Production of reactive oxygen species by spermatozoa undergoing cooling, freezing and thawing. Mol Reprod Dev 2001; 59(4): 451-458

[39]Naijian HR, Kohram H, Shahneh AZ, Sharafi M, Bucak MN. Effects of different concentrations of BHT on microscopic and oxidative parameters of Mahabadi goat semen following the freeze-thaw process. Cryobiology 2013; 66(2): 151-155.

[40]Bamba K, Cran DG. Effect of treatment with butylated hydroxytoluene on the susceptibility of boar spermatozoa to cold stress and dilution. $J$ Reprod Fertil 1992; 95(1): 69-77.

[41]Hammerstedt RH, Amann RP, Rucinsky T, Morse PD, Lepock J, Snipes $\mathrm{W}$, et al. Use of spin labels and electron spin resonance spectroscopy to characterize membranes of bovine sperm: Effect of butylated hydroxytoluene and cold shock. Biol Reprod 1976; 14(4): 381-397.

[42]Pursel VG. Effect of cold shock on boar sperm treated with butylated hydroxytoluene. Biol Reprod 1979; 21(2): 319-324.

[43]Watson PF. The cause of reduced fertility with cryopreserved semen. Anim Reprod Sci 2000; 61: 481-492.

[44]Williams GM, Iatropoulos MJ, Whysner J. Safety assessment of butylated hydroxyanisole and butylated hydroxytoluene as antioxidant food additives. Food Chem Toxicol 1999; 37(9-10): 1027-1038.

[45]Ball BA, Medina V, Gravance CG, Bumber J. Effect of antioxidants on preservation of motility, viability and acrosomal integrity of equine spermatozoa during storage at 5 degrees C. Theriogenology 2001; 56(4): 577-589.

[46]Baumber J, Ball BA, Gravance CG, Medina V, Davies-Morel MCG. The effect of reactive oxygen species on equine sperm motility, viability, acrosomal integrity, mitochondrial membrane potential and membrane lipid peroxidation. J Androl 2000; 21(6): 895-902.

[47]Satorre MM, Breininger E, Beconi MT, Beorlegui NB. $\alpha$-Tocopherol modifies tyrosine phosphorylation and capacitationlike state of cryopreserved porcine sperm. Theriogenology 2007; 68(7): 958-965. 